Article

\title{
Post-Fire Mechanical Properties of Concrete Reinforced with Spanish Broom Fibers
}

\author{
Sandra Juradin ${ }^{1, * \mathbb{D}}$, Lidia Karla Vranješ ${ }^{2}$, Dražan Jozić ${ }^{3}$ and Ivica Boko $^{1}$ (D) \\ 1 Faculty of Civil Engineering, Architecture and Geodesy, University of Split, Matice Hrvatske 15, \\ 21000 Split, Croatia; ivica.boko@gradst.hr \\ 2 Komjate d.o.o., Put Kruga 9, 21212 Kaštel Sućurac, Croatia; lidia.komjate@gmail.com \\ 3 Faculty of Chemistry and Technology, University of Split, Ruđera Boškovića 35, 21000 Split, Croatia; \\ jozicd@ktf-split.hr \\ * Correspondence: sandra.juradin@gradst.hr; Tel.: +385-21-303-339
}

check for updates

Citation: Juradin, S.; Vranješ, L.K.; Jozić, D.; Boko, I. Post-Fire Mechanical Properties of Concrete Reinforced with Spanish Broom Fibers. J. Compos. Sci. 2021, 5, 265. https://doi.org/10.3390/jcs5100265

Academic Editors: Baljinder Kandola and Francesco Tornabene

Received: 31 August 2021

Accepted: 27 September 2021

Published: 11 October 2021

Publisher's Note: MDPI stays neutral with regard to jurisdictional claims in published maps and institutional affiliations.

Copyright: (c) 2021 by the authors. Licensee MDPI, Basel, Switzerland. This article is an open access article distributed under the terms and conditions of the Creative Commons Attribution (CC BY) license (https:// creativecommons.org/licenses/by/ $4.0 /)$.

\begin{abstract}
In this study, we conducted an initial investigation of the post-fire mechanical properties of concrete reinforced with Spanish broom fibers. The mechanical properties were determined at room temperature, and the post-fire mechanical properties were determined at elevated temperature, so that the fire resistance of the concrete could be determined. Five mixtures were considered: three with differently treated Spanish broom fibers, a polypropylene fiber mixture, and a reference concrete mixture. The concrete and reinforced concrete samples were first dried to $100{ }^{\circ} \mathrm{C}$, then heated to $400{ }^{\circ} \mathrm{C}$, and left to cool to room temperature. The samples were tested immediately and $96 \mathrm{~h}$ after cooling. The compressive strength, weight loss, ultrasonic pulse velocity, and dynamic modulus of elasticity were determined and compared. The cross-sectional images of the concrete samples captured through an optical microscope were observed and analyzed. The changes in fiber structure were monitored by TG/DTG analysis. The results of the study indicate that even the reference concrete mixture did not have satisfactory residual properties. The reinforced concretes did not improve the residual properties of the reference concrete, but reduced the spalling and explosive failure performance under a compressive load. The concrete reinforced with Spanish broom fibers showed improved residual properties compared with concrete reinforced with polypropylene fibers.
\end{abstract}

Keywords: concrete; Spanish broom fibers; fire resistance; residual properties; cooling time; thermogravimetry-differential thermal analysis

\section{Introduction}

Concrete is a composite material that is widely used in buildings, industrial infrastructure, and other applications around the world. Nowadays, structures are increasing in size and complexity [1]. This has led to developments in fiber-reinforced concrete to overcome the limitations of conventional concrete. The use of fibers in concrete provides advantages by enhancing the compressive strength, tensile strength, and ductile behavior of conventional concrete, along with the durability, crack resistance, and fire resistance [2]. The fibers can be continuous or discontinuous and of various shapes and sizes [3]. They are produced from steel, synthetics, glass, and natural materials, with steel fibers being the most used [3].

Although concrete, as an inert material, performs better at high temperatures and has a higher capacity to endure fire than other materials due to its low thermal conductivity and non-combustibility, the damaging impacts of fire on the mechanical properties and durability of concrete remain a concern to many researchers $[1,4]$. Some of the types of fire damage to concrete include explosive spalling, strength loss, and cracking [5]. Deterioration in the mechanical properties is attributed to physicochemical changes in the cement paste and aggregate, and the thermal incompatibility between them, which occurs in relation to the compressive and tensile strength [6]. The critical exposure temperature range for loss 
of compressive strength is $400-800{ }^{\circ} \mathrm{C}$ [5]. Most of the original strength is lost between 600 and $800^{\circ} \mathrm{C}$, where concrete is not structurally useful $[5,6]$.

Steel fibers can support the structure of concrete at high temperatures due to their high melting point [1]. A previous study [7] showed that the more steel fibers included in the concrete, the higher the compressive strength at high temperatures. With increasing temperature, the compressive values decrease, with the highest values occurring for the samples containing increased amounts of steel fibers. Lau [8] also reported a higher overall residual strength and better crack resistance of steel-fiber-reinforced concrete after exposure to high temperatures. The mechanism of polypropylene fibers when exposed to high temperatures is the most efficient amongst those of synthetic fibers because they melt at $170{ }^{\circ} \mathrm{C}$ and create a porous structure, which reduces the build-up of pore pressure inside the heated concrete structure [9]. They perform better than steel fibers in preventing spalling, although they negatively affect the concrete's other mechanical properties, since they reduce the remaining compressive strength, modulus of elasticity, and tensile strength of the fired concrete $[4,10]$. Conclusions on the use of PP fibers and their influence on the fire resistance of concrete or mortar are conflicting. For instance, Xiao and Falkner [9] stated that PP fibers increase the relative residual compressive strength and decrease the residual flexural strength of concrete. Other authors [11] stated that the residual strength of concrete is not influenced by the inclusion of PP fibers when exposed to temperatures ranging from $200-800{ }^{\circ} \mathrm{C}$. Kalifa [12] reported that these fibers demonstrated a beneficial influence on the residual strength of concrete after exposure to high temperatures.

In an attempt to find more sustainable construction materials, researchers have shifted to exploring natural fibers as alternatives to steels and synthetic fibers in cement composites, especially regarding their performance in fire conditions [4]. The most commonly used and analyzed fibers are plant fibers [13], which are sustainable, renewable, and widely available. Although they cost less and require less energy to produce than glass or carbon fibers, their drawbacks include the inconsistency of their properties and their quality [13]. The wide variability in the fibers leads to unpredictable mechanical properties of reinforced concrete in fresh and hardened states. The main factors that significantly affect the properties of natural-fiber-reinforced concrete are the fiber type, length, and volume concentration [14]. The addition of fibers to a concrete mix can decrease the workability, create the balling effect, and decrease the concrete strength in hardened states [14]. The key for certain fibers is to find the optimum fiber length and volume content [14].

Many studies have investigated the performance of natural-fiber-reinforced concrete at ambient temperature, analyzing the fiber characteristics, microstructure, mechanical properties, durability, and structural and nonstructural applications [4,15-22]; however, only $6 \%$ of natural-fiber-reinforced concrete studies have examined the concrete's properties after exposure to elevated temperatures [4]. The unpredictable nature of the fibers results in unpredictable performance of natural-fiber-reinforced concrete under exposure to elevated temperatures; however, the fibers are not the only factor that affects the fire resistance of natural-fiber-reinforced concrete: it also depends on the composition of the concrete [4]. Ede and Aina [23] investigated the effects of fire on coconut husk fiber- and polypropylenefiber-reinforced concrete, whereby $0.5 \%$ of coconut and $0.5 \%$ of polypropylene fibers were used in a fiber-reinforced concrete. The fiber-reinforced concrete was exposed to temperatures of $200,400,600,800$, and $1000{ }^{\circ} \mathrm{C}$ after $7,14,21$, and 28 days of curing. At 28 days, the coconut-fiber-reinforced concrete exhibited approximately $19 \%$ strength gain at ambient temperature and $11 \%$ residual strength gain after exposure to $1000{ }^{\circ} \mathrm{C}$ in comparison to ordinary concrete. The results showed that the addition of coconut fibers improved the strength and fire resistance of the concrete, performing even better than polypropylene fibers.

Anowai and Job [24] investigated the durability properties of banana-fiber-reinforced ash concrete with incorporating $0 \%, 10 \%, 20 \%, 30 \%$, or $40 \%$ fly ash and a $0.5 \%$ volume fraction of $30 \mathrm{~mm}$ long banana fibers. After being cured in water for up to 90 days, some samples were immersed in $5 \%$ sulfuric acid, magnesium sulfate, and sodium chloride 
solutions for 28 days. The samples were exposed to 200,400 and $600{ }^{\circ} \mathrm{C}$, and their residual properties were determined after the exposure. The results showed the better performance of banana-fiber-reinforced concrete in terms of losses in compressive strength over plain and other concrete samples after exposure to 200 and $400{ }^{\circ} \mathrm{C}$. They concluded that the fire resistance of banana-fiber-reinforced concrete can be improved by partially replacing cement with fly ash.

In a similar study, the compressive strength of sisal fibrous ternary concrete at elevated temperatures was investigated by Nwankwo and Achuenu [25], where the specimen with $30 \%$ fly ash and $20 \%$ calcined waste crushed clay bricks demonstrated good thermal strength between 100 and $600{ }^{\circ} \mathrm{C}$ [4]. They recorded a reduction of $24 \%$ in compressive strength after exposure to $600{ }^{\circ} \mathrm{C}$ compared with all the other specimens. Netinger Grubeša et al. [26] studied the use of hemp fibers for improving the fire resistance of concrete. The aim was to determine how different hemp fiber treatments influence concrete's properties at ambient temperature and whether hemp fibers can be used to improve the fire resistance of concrete, determining it after the exposure of samples to $400{ }^{\circ} \mathrm{C}$. The results showed that the addition of any type of fiber increased the initial compressive strength of the reference concrete by $2-12 \%$. The authors reported that the addition of hemp fibers to concrete could improve the fire resistance of concrete through incompletely disintegrated hemp fibers that could be used to prevent further crack propagation at higher temperatures.

The application of natural, cellulose fibers is an advantage when they are locally available. A local plant, Spanish broom, well-known in the Mediterranean area, especially for its tough and almost indivisible fibers, has shown considerable potential for future investigations into its use in fiber reinforced cement composites [27-31]. The branches of the Spanish broom consists of the inner rigid woody part and outer layer with elemental and technical fibers [27]. The fibers can be extracted by mechanical maceration, biological maceration (soaking the sticks in seawater) and chemical maceration (soaking in sodium hydroxide) [28-32]. Alkaline treatment helps to break the bundles of fibers into individual fibers [33]. The aim of this investigation is to determine the effect of Spanish broom fibers on the fire resistance of concrete. The mechanical properties at ambient temperature and residual properties of such fiber reinforced concrete is determined after exposure to $100{ }^{\circ} \mathrm{C}$ and $400{ }^{\circ} \mathrm{C}$. Residual properties are analyzed according to different cooling times $(0$ and $96 \mathrm{~h}$ after cooling). Additionally, a comparison is provided with ordinary concrete and concrete reinforced with polypropylene fibers. This is an initial study of concrete reinforced with Spanish broom fibers and it shows a guideline in which further investigations can be obtained.

\section{Materials and Methods}

\subsection{Materials}

For the purposes of this study, five concrete mixtures were prepared: a reference mixture without fibers and four mixtures with fibers. All mixtures were prepared with crushed limestone aggregate, with fractions corresponding to $0-4,4-8$, and $8-16 \mathrm{~mm}$. The particle size distribution of the aggregate and concrete is shown in Figure 1. Portland cement CEM I 42.5 R, (Cemex Hrvatska d.d., K. Sućurac, Croatia), complying with the HRN EN 197-1 requirements [34], was used for the preparation of all concrete mixtures. X-ray diffraction (XRD) measurements were performed using a Malvern Panalytical Empyrean diffractometer (Almelo, The Netherlands). The XRD analysis of Portland cement (type CEM I 42.5 R) was performed using a system with the following operating conditions: $\mathrm{Cu}-\mathrm{Ka}, 40 \mathrm{kV}$ voltage, $40 \mathrm{~mA}$ current, and a PIXcel3D Detector with Medipix3. Diffraction patterns were collected using a gonio scan with a step size of $0.0263^{\circ}$ and scanning angle

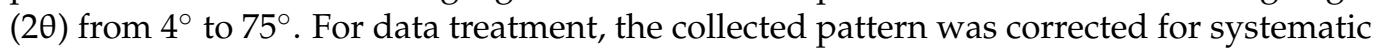
errors (external Si standard). The XRD pattern was qualitatively interpreted in comparison to standard patterns contained in the PDF2 database (ICDD, PDF2 Released 2020) using HighScore Plus. Quantitative analysis was performed using the direct derivative (DD) 
quantification method [35]. Based on the XRD pattern [28], the mineral composition of CEM I $42.5 \mathrm{R}$ cement is shown in Table 1. All mixtures were prepared with the same amount of cement $\left(400 \mathrm{~kg} / \mathrm{m}^{3}\right)$, with a water/cement ratio of 0.48 . Two types of fibers were used for the purposes of this research: polypropylene fibers and Spanish broom fibers. The amount of each sort of fiber was $1 \%$ of the total volume, based on $[26,28]$.

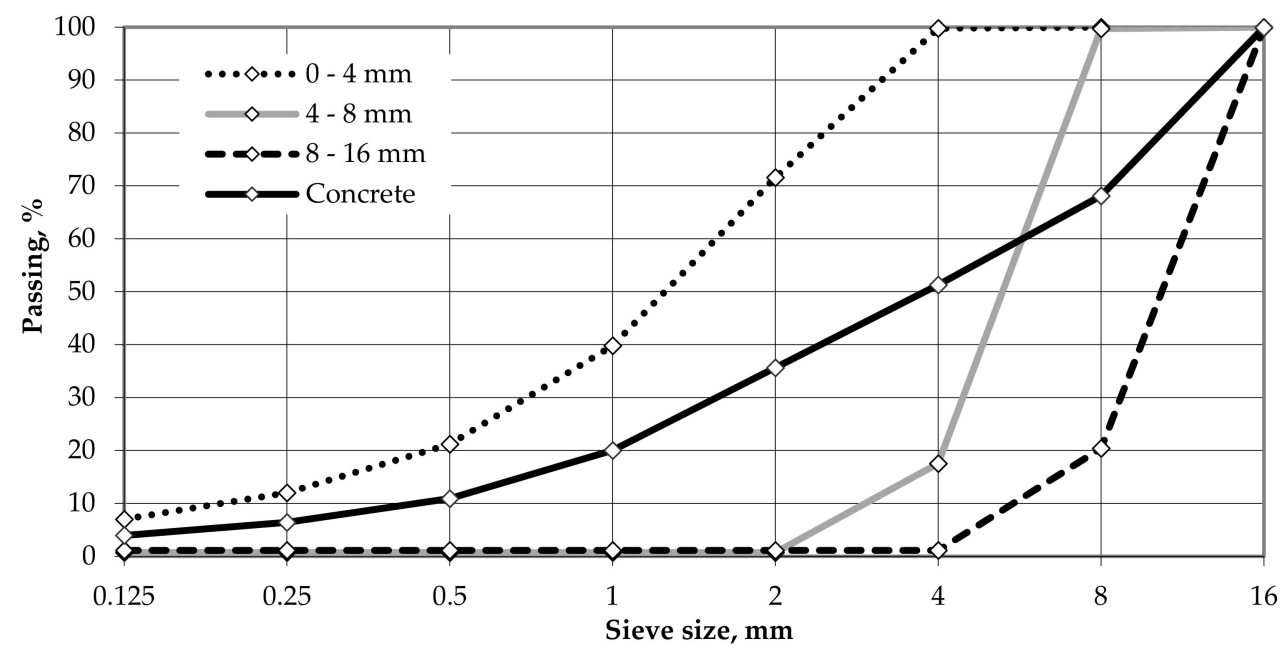

Figure 1. Particle size distribution of the aggregate and cumulative sieving curve of concrete.

Table 1. The mineral composition of CEM I $42.5 \mathrm{R}$ cement based on the X-ray diffraction pattern [28].

\begin{tabular}{cc}
\hline Mineral & wt \% \\
\hline $\mathrm{C}_{3} \mathrm{~S}$ & 75.4 \\
\hline $\mathrm{\beta C}_{2} \mathrm{~S}$ & 10.7 \\
\hline $\mathrm{C}_{3} \mathrm{~A}$ & 0.7 \\
\hline $\mathrm{C}_{4} \mathrm{AF}$ & 11.7 \\
\hline $\mathrm{CSH}_{2}$ & 0.2 \\
\hline $\mathrm{CaSO}_{4}$ anhydrite & 0.9 \\
\hline $\mathrm{MgO}$ & 0.4 \\
\hline
\end{tabular}

\subsection{Preparation and Thermal Analysis (TGA/DSC) of Fibers}

Polypropylene (PP) fibers with a length of $12 \mathrm{~mm}$ were purchased from KEM-GRAD, Dugo Selo (Croatia). The Spanish broom (SB) fibers were prepared internally for this test because they are not available on the market. The Spanish broom was harvested in the summertime. Branches were cut and the fibers were then extracted by biological and chemical maceration. One group of branches was submerged in seawater for 40 days (biological; Figure 2a). The second was immersed in a solution of $5 \%$ sodium hydroxide for 24 days; the third was immersed in a solution of $15 \%$ sodium hydroxide for 7 days (chemical). The production of fibers using maceration processes can also be considered for the treatment of fibers. After all the three fiber treatment procedures were complete, the fibers were then extracted by rinsing the branches under the tap water and separating the outer fibrous parts of the shoots from the wood. The fibers were left to dry at room temperature until further use (Figure 2b). The cellulosic Spanish broom fibers were manually cut to the length of the artificial polypropylene fibers, which were $12 \pm 2 \mathrm{~mm}$ long. The fibers were marked with SB-5 for SB fibers treated with 5\% NaOH, SB-15 for fibers SB fibers treated with 15\% $\mathrm{NaOH}$, and SB-S40 for SB fibers treated for 40 days with seawater. 


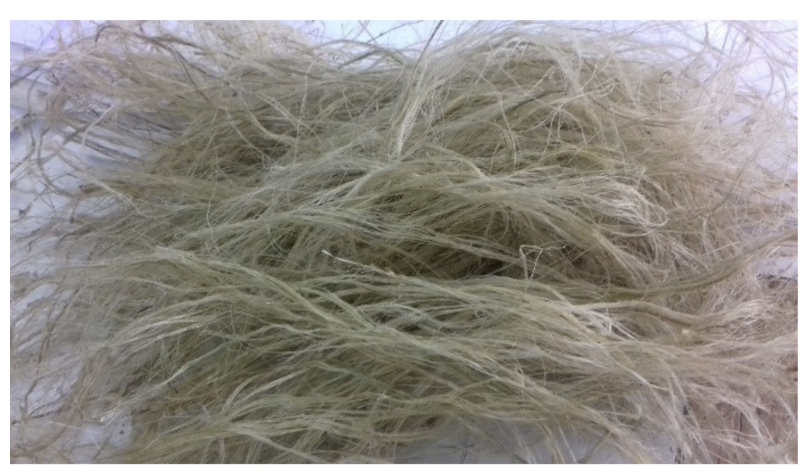

(a)

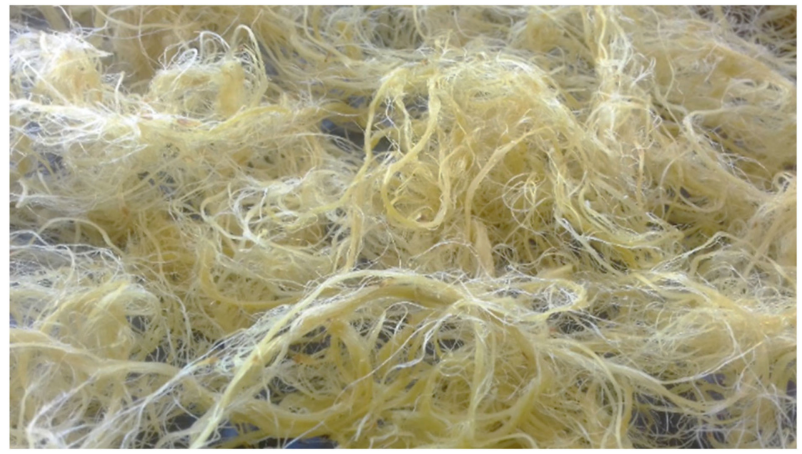

(b)

Figure 2. (a) Dry Spanish broom fibers treated with seawater; (b) drying Spanish broom fibers treated with $5 \% \mathrm{NaOH}$.

The thermal properties of Spanish broom fibers prepared by maceration and PP fibers were determined using an instrument for thermogravimetry-differential thermal analysis (TG/DTA; Pyris Diamond device, Perkin Elmer, Waltham, MA, USA). Thermal properties were measured in the temperature range of 30 to $550{ }^{\circ} \mathrm{C}$, at a heating rate of $20^{\circ} \mathrm{C} / \mathrm{min}$. Measurements were recorded in an inert atmosphere using nitrogen as a purge gas, with a constant flow rate of $100 \mathrm{~mL} / \mathrm{min}$. The thermogravimetry curves and their derivation curves (TG/DTG) of natural Spanish broom fibers prepared by maceration (SB-5, SB-15, and SB-S40) and the TG/DTG-DTA curve of polypropylene (PP) fibers are shown in Figure 3.

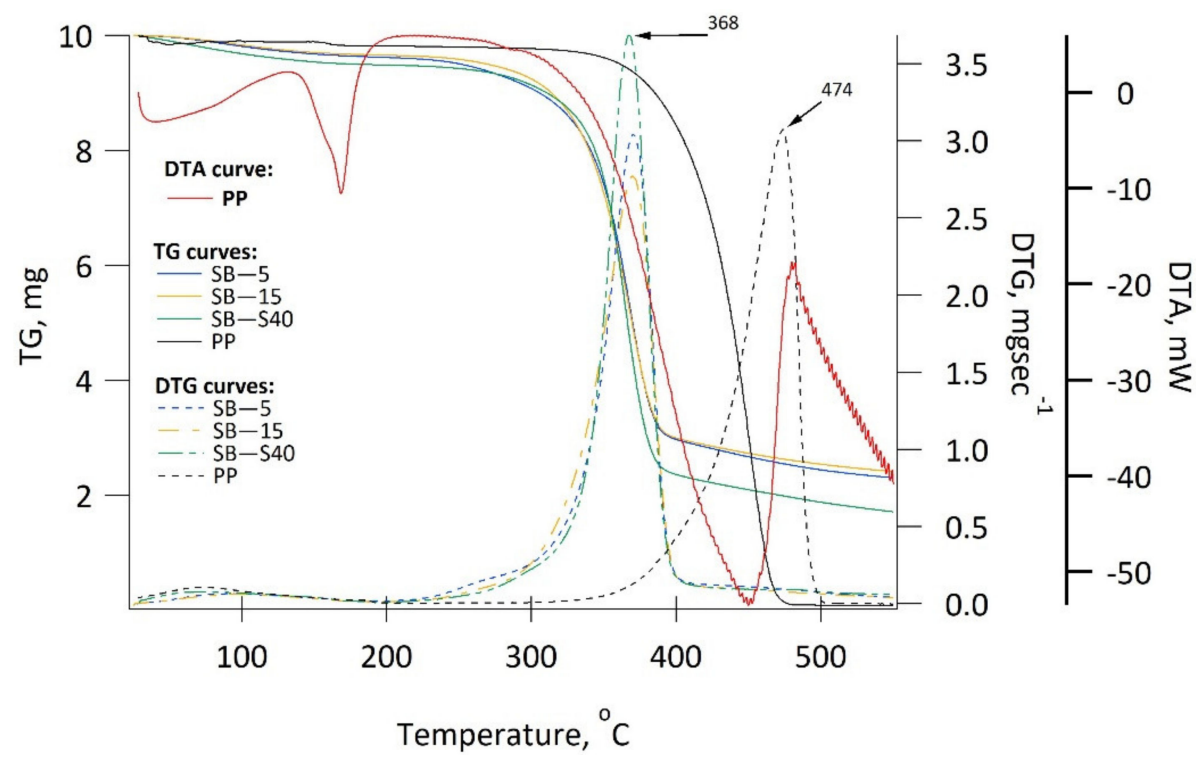

Figure 3. TG/DTG curves of SB-5, SB-15, SB-S40, and PP fibers.

From the obtained results of the thermal stability test, the DTA curve shows that the PP fibers had a melting temperature of $143^{\circ} \mathrm{C}$. At this temperature, the PP fibers began to soften and with increasing temperature, they transformed into a molten mass within the formed and hardened spaces in the cement matrix. Increasing the sample temperature to above $307^{\circ} \mathrm{C}$ influenced the thermal degradation of PP fibers. The degree of degradation of PP fibers, which was measured from the mass loss (TG curve) at a temperature of $400{ }^{\circ} \mathrm{C}$, was $13.27 \mathrm{wt} \%$. A further increase in temperature contributed to an increase in the degree of degradation of PP fibers, ending at a temperature of $485^{\circ} \mathrm{C}$. Compared to the fibers obtained from the Spanish broom by maceration, PP firers show better thermal stability. The beginning of the thermal decomposition of the studied Spanish broom fibers (SB-5, SB-15, and SB-S40) was already visible at $231^{\circ} \mathrm{C}$, where the decomposition of hemicellulose began 
and the process of cellulose decomposition also simultaneously began. The decomposition process successfully finished at $400{ }^{\circ} \mathrm{C}$.

\subsection{Preparation of Concrete Mixtures}

All types of mixtures with their constituents and labels are shown in Table 2. Fiberreinforced mixtures are marked the same as the types of fibers they contain, while the reference mixture is labelled $\mathrm{E}$. The mixing procedure was the same for all mixtures. In the laboratory pan mixer, coarse aggregates were placed in the mixer first, followed by sand, cement, and then fibers. To avoid the balling effect in mixtures, the fibers were manually separated and spread in the mixer evenly (Figure 4a). The solid components of the mixtures were dry-mixed for about $1 \mathrm{~min}$. After the initial mixing, water was added to the mixtures and through 5 min of further mixing, a fresh concrete mix was obtained.

Table 2. Concrete mixtures.

\begin{tabular}{ccccccc}
\hline Constituent/Mixtures & E & PP & SB-5 & SB-15 & SB-S40 \\
\hline Cement $\left(\mathrm{kg} / \mathrm{m}^{3}\right)$ & 400 & 400 & 400 & 400 & 400 \\
\hline \multirow{2}{*}{ Water/cement ratio } & 0.48 & 0.48 & 0.48 & 0.48 & 0.48 \\
\cline { 2 - 7 } Aggregate & $0-4 \mathrm{~mm}\left(\mathrm{~kg} / \mathrm{m}^{3}\right)$ & 913.9 & 900.9 & 900.9 & 900.9 & 900.9 \\
\cline { 2 - 7 } & $4-8 \mathrm{~mm}\left(\mathrm{~kg} / \mathrm{m}^{3}\right)$ & 205 & 202.2 & 202.2 & 202.2 & 202.2 \\
\cline { 2 - 7 } & $8-16 \mathrm{~mm}\left(\mathrm{~kg} / \mathrm{m}^{3}\right)$ & 746.4 & 735.4 & 735.4 & 735.4 & 735.4 \\
\hline \multirow{4}{*}{ Fibers } & PP fibers $\left(\mathrm{kg} / \mathrm{m}^{3}\right)$ & - & 9.1 & - & - & - \\
\cline { 2 - 7 } & $\mathrm{SB}-5$ fibers $\left(\mathrm{kg} / \mathrm{m}^{3}\right)$ & - & - & 10 & - & - \\
\cline { 2 - 7 } & $\mathrm{SB}-15$ fibers $\left(\mathrm{kg} / \mathrm{m}^{3}\right)$ & - & - & - & 10 & - \\
\cline { 2 - 7 } & SB-S40 fibers $\left(\mathrm{kg} / \mathrm{m}^{3}\right)$ & - & - & - & - & 10 \\
\hline
\end{tabular}

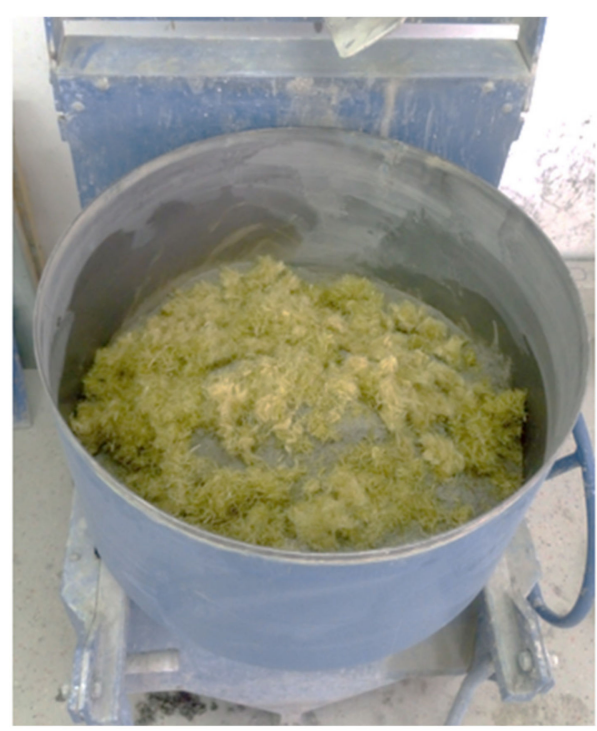

(a)

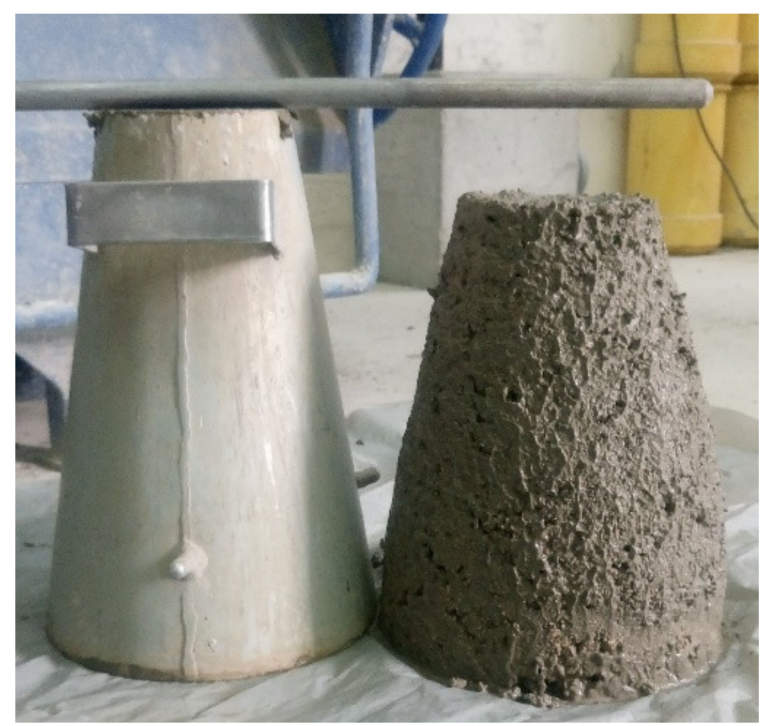

(b)

Figure 4. (a) Separated Spanish broom fibers in the pan mixer; (b) a slump of reference mixture E.

\subsection{Testing of Fresh Concrete}

The properties of fresh concrete were determined, and are shown in Table 3. The density of fresh concrete was measured in accordance with HRN EN 12350-6 [36], air content in accordance with HRN EN 12350-7 [37], and the consistency in accordance with HRN EN 12350-2 [38] (Figure 4b), and the temperature was tested with a digital 
thermometer, in accordance with HRN U.M1.032:1981 [39]. According to Table 3, mixtures with fibers had $3.7 \%$ to $5.4 \%$ lower density compared to the reference mixture, as well as lower workability. Bamigboye et al. [40] obtained similar result; they varied the percentages of coconut fibers from $0-1 \%$ and they found that the increase in fiber content beyond $0.5 \%$ decreased the workability of the concrete.

Table 3. Properties of fresh concrete mixtures.

\begin{tabular}{cccccc}
\hline Mixture & E & PP & SB-5 & SB-15 & SB-S40 \\
\hline $\begin{array}{c}\text { Density } \\
\left(\mathrm{kg} / \mathrm{m}^{3}\right)\end{array}$ & 2466 & 2374 & 2370 & 2332 & 2353 \\
\hline $\begin{array}{c}\text { Air content } \\
(\%)\end{array}$ & 3.2 & 2.8 & 2.8 & 3.2 & 3.8 \\
\hline $\begin{array}{c}\text { Temperature } \\
\left({ }^{\circ} \mathrm{C}\right)\end{array}$ & 19.2 & 21.1 & 19.7 & 19.2 & 19.5 \\
\hline $\begin{array}{c}\text { Slump test } \\
(\mathrm{mm})\end{array}$ & 50 & 0 & 10 & 10 & 0 \\
\hline
\end{tabular}

The mixtures were cast into cylinders with a height equal to three times the diameter (225 mm/75 mm) in accordance with RILEM requirements, the maximum aggregate size, and previous studies [41-43]. After the specimens were demolded for the first $24 \mathrm{~h}$, they were placed in a water tank for 6 days. Further curing and storage occurred in a storage chamber with an air temperature of $20 \pm 2{ }^{\circ} \mathrm{C}$ and relative humidity $(\mathrm{RH})$ of $50 \pm 5 \%$ until the beginning of testing in a hardened state. The total curing time was around 140 days, respecting the conditions that RILEM recommends: specimens should be older than 90 days [42].

\subsection{Heating and Cooling Regime of the Concrete Test Specimens: Testing of Hardened Concrete Specimens}

The specimens were prepared for testing according to the recommendations [42]: the ends of the specimen should be nominally parallel, flat, and orthogonal to its central axis. Five series of specimens were prepared for each concrete mixture, for a total of 60 cylinders. For each mixture with Spanish broom fibers, 10 specimens were fabricated due to the limited amount of processed fibers, and 15 specimens for the E and PP mixtures. Before exposing the specimens to the target temperature of $400{ }^{\circ} \mathrm{C}$, they were dried in an oven at $100 \pm 5{ }^{\circ} \mathrm{C}$ for $24 \pm 2 \mathrm{~h}$ to remove free water from the samples and establish constant sample weight. After drying, the samples were transferred to a furnace.

The heating condition is shown in Figure 5. The heating rate of the specimen was $2{ }^{\circ} \mathrm{C} / \mathrm{min}$. After reaching a maximum temperature of $400{ }^{\circ} \mathrm{C}$, which was selected due to the initial stage of crack formation in concrete in general, the temperature was maintained for a period of $2.5 \mathrm{~h}$. After accomplishing a uniform temperature distribution in the mentioned time, the specimens were cooled in the furnace until they reached room temperature at a rate of $1{ }^{\circ} \mathrm{C} / \mathrm{min}$.

Tests and measurements performed in this investigation were: height, diameter, and weight of specimens; ultrasonic pulse velocity (UPV) according toHRN EN 12504-4 [44]; and dynamic modulus of elasticity based on the UPV and compressive strength according to HRN EN 12390-3 [45]. The dynamic modulus of elasticity was calculated assuming a Poisson's ratio $(\mu)$ of 0.20 for all temperatures and cooling times. This value was selected based on [46], in which it is stated that the Poisson's ratio ranged from 0.11 to 0.25 at 20 to $400{ }^{\circ} \mathrm{C}$. Above $400{ }^{\circ} \mathrm{C}$, Poisson's ratio increases, which is not related to this examination. These tests were performed on specimens at room temperature, after drying at $100{ }^{\circ} \mathrm{C}$, and after exposure to a target temperature of $400{ }^{\circ} \mathrm{C}$. For temperatures of 100 and $400{ }^{\circ} \mathrm{C}$, the specimens were tested 0 and $96 \mathrm{~h}$ after cooling. At room temperature, the weight, UPV, and dynamic modulus of elasticity were determined on all specimens of each mixture. At $100{ }^{\circ} \mathrm{C}(0 \mathrm{~h})$ the weight, UPV, and dynamic modulus of elasticity were determined, as well 
as for room temperature, but only using the specimens for which the compressive strength had not been tested at room temperature. At other temperatures and cooling times, three and two specimens, respectively, were tested for all the above properties: three specimens for EE and PP mixtures and two specimens for SB concretes.

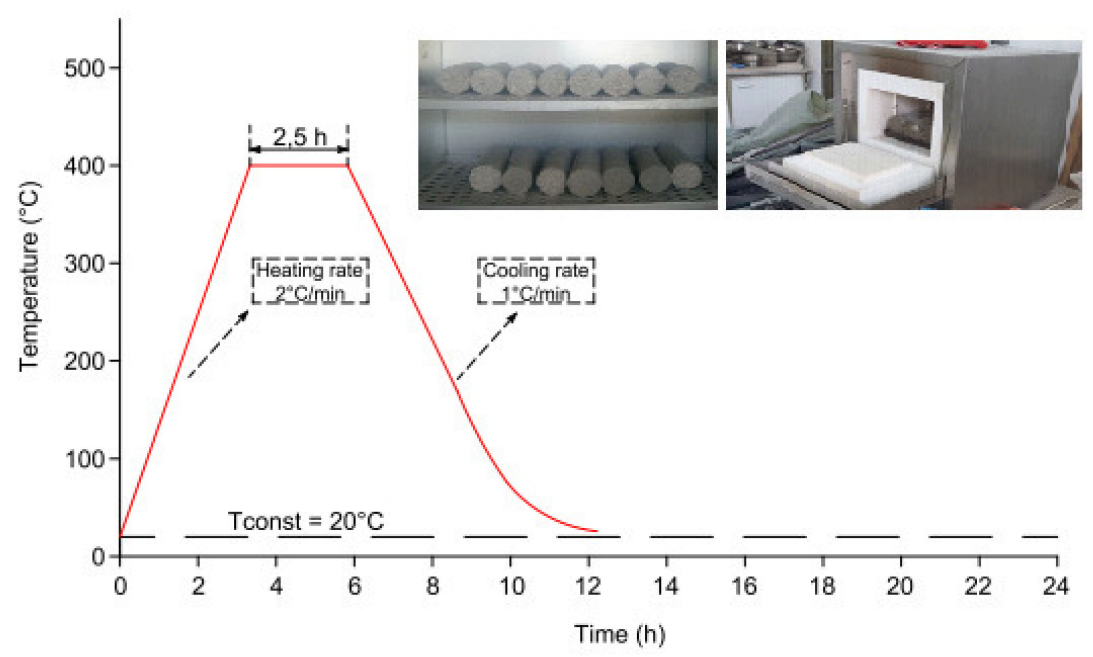

Figure 5. Heating conditions in the furnace; specimens in the dryer and furnace.

\section{Results and Discussion}

The initial values and reductions in values in accordance with the temperature exposure and cooling regime of all concrete and reinforced concrete samples are shown in Table 4.

Table 4. Initial and residual values of heated concrete properties with the standard deviation of each property.

\begin{tabular}{|c|c|c|c|c|c|c|c|}
\hline Properties & $\begin{array}{l}\text { Temp } \\
\left({ }^{\circ} \mathrm{C}\right)\end{array}$ & $\begin{array}{l}\text { Time } \\
\text { (h) }\end{array}$ & E & PP & SB-5 & SB-15 & SB-S40 \\
\hline \multirow{5}{*}{ Weight (g) } & 20 & 0 & $2324 \pm 47.9$ & $2286 \pm 52.4$ & $2312 \pm 19.0$ & $2316 \pm 13.5$ & $2320 \pm 18.0$ \\
\hline & \multirow{2}{*}{100} & 0 & $2272 \pm 18.0$ & $2229 \pm 11.3$ & $2240 \pm 23.7$ & $2256 \pm 8.9$ & $2263 \pm 13.8$ \\
\hline & & 96 & $2204 \pm 71.8$ & $2183 \pm 113.2$ & $2264 \pm 8.7$ & $2252 \pm 9.6$ & $2233 \pm 6.7$ \\
\hline & \multirow{2}{*}{400} & 0 & $2238 \pm 30.8$ & $2192 \pm 17.6$ & $2200 \pm 2.7$ & $2221 \pm 12.5$ & $2220 \pm 14.3$ \\
\hline & & 96 & $2247 \pm 7.6$ & $2195 \pm 3.4$ & $2201 \pm 46.9$ & $2226 \pm 11.5$ & $2237 \pm 16.3$ \\
\hline \multirow{5}{*}{$\begin{array}{l}\text { Ultrasonic } \\
\text { pulse velocity } \\
(\mathrm{m} / \mathrm{s})\end{array}$} & 20 & 0 & $4286 \pm 38.5$ & $4027 \pm 52.4$ & $4081 \pm 34.2$ & $4027 \pm 24.6$ & $4022 \pm 52.6$ \\
\hline & \multirow{2}{*}{100} & 0 & $4033 \pm 24.1$ & $3611 \pm 25.8$ & $3659 \pm 53.1$ & $3640 \pm 44.8$ & $3583 \pm 156.5$ \\
\hline & & 96 & $3937 \pm 51.4$ & $3573 \pm 107.4$ & $3696 \pm 38.4$ & $3678 \pm 18.4$ & $3730 \pm 36.4$ \\
\hline & \multirow{2}{*}{400} & 0 & $2754 \pm 20.8$ & $2466 \pm 11.3$ & $2622 \pm 5.0$ & $2547 \pm 52.1$ & $2488 \pm 125.7$ \\
\hline & & 96 & $2784 \pm 51.7$ & $2468 \pm 29.9$ & $2507 \pm 48.2$ & $2561 \pm 18.7$ & $2567 \pm 16.3$ \\
\hline \multirow{5}{*}{$\begin{array}{l}\text { Dinamic } \\
\text { modulus of } \\
\text { elasticity } \\
(\mathrm{GPa})\end{array}$} & 20 & 0 & $38.77 \pm 1.1$ & $33.62 \pm 1.3$ & $34.79 \pm 0.6$ & $33.96 \pm 0.5$ & $33.93 \pm 0.9$ \\
\hline & \multirow{2}{*}{100} & 0 & $33.47 \pm 0.5$ & $26.31 \pm 0.4$ & $27.13 \pm 0.9$ & $27.03 \pm 0.6$ & $26.28 \pm 2.3$ \\
\hline & & 96 & $31.38 \pm 1.8$ & $25.46 \pm 2.4$ & $27.94 \pm 0.6$ & $27.57 \pm 0.4$ & $28.14 \pm 0.5$ \\
\hline & \multirow{2}{*}{400} & 0 & $15.36 \pm 0.4$ & $12.05 \pm 0.1$ & $13.69 \pm 0.1$ & $13.02 \pm 0.6$ & $12.41 \pm 1.3$ \\
\hline & & 96 & $15.77 \pm 0.6$ & $12.09 \pm 0.2$ & $12.53 \pm 0.7$ & $13.19 \pm 0.3$ & $13.32 \pm 0.2$ \\
\hline \multirow{5}{*}{$\begin{array}{l}\text { Compressive } \\
\text { strength } \\
(\mathrm{MPa})\end{array}$} & 20 & 0 & $45.05 \pm 2.6$ & $48.52 \pm 4.0$ & $50.74 \pm 2.7$ & $45.46 \pm 4.3$ & $50.64 \pm 3.9$ \\
\hline & \multirow{2}{*}{100} & 0 & $35.86 \pm 4.9$ & $44.43 \pm 2.2$ & $42.50 \pm 4.1$ & $47.75 \pm 0.6$ & $42.52 \pm 1.2$ \\
\hline & & 96 & $38.80 \pm 5.6$ & $39.78 \pm 5.9$ & $43.94 \pm 0.0$ & $39.50 \pm 5.3$ & $42.31 \pm 1.8$ \\
\hline & \multirow{2}{*}{400} & 0 & $25.99 \pm 2.6$ & $21.90 \pm 2.3$ & $24.48 \pm 0.5$ & $23.86 \pm 1.3$ & $21.30 \pm 4.6$ \\
\hline & & 96 & $25.51 \pm 1.5$ & $18.56 \pm 2.9$ & $20.70 \pm 0.7$ & $20.36 \pm 1.9$ & $20.67 \pm 0.1$ \\
\hline
\end{tabular}


The weight of the samples represented in Table 4 shows that there was no significant loss in specimens mass. The loss was between $2 \%$ and $5 \%$, which is consistent with previously reported results [47]. A mass gain only occurred over the test period in specimens exposed at $400{ }^{\circ} \mathrm{C}$, ranging from $0.05 \%$ to $0.8 \%$ compared with the specimen mass at the beginning of the test period, due to moisture intrusion. In terms of dynamic modulus of elasticity, the residual values decreased with an increase in temperature, regardless of the cooling time of the samples. After drying, the values decreased by around $20 \%$, whereas after heating, the value fell by around $60 \%$ for both cooling time, (Table 4 and Figure 6). The values of the dynamic modulus of elasticity of the concrete specimens reinforced with Spanish broom fibers are between the values of ordinary concrete and concrete reinforced with polypropylene fibers (Figure 6). At $400^{\circ} \mathrm{C}$ for both cooling times, all values are within a $5 \%$ difference. Comparing the values of the fiber reinforced concrete to the values of ordinary concrete for each temperature and cooling time shown in Figure 7, the values of concrete reinforced with Spanish broom fibers have better properties than those with polypropylene fibers. The values of the dynamic modulus of elasticity of reinforced concrete are $10 \%$ to $23 \%$ less than those of the reference mixture for all test temperatures and cooling times. The maceration method of Spanish broom fibers did not affect the value of the dynamic modulus of elasticity of SB concretes.

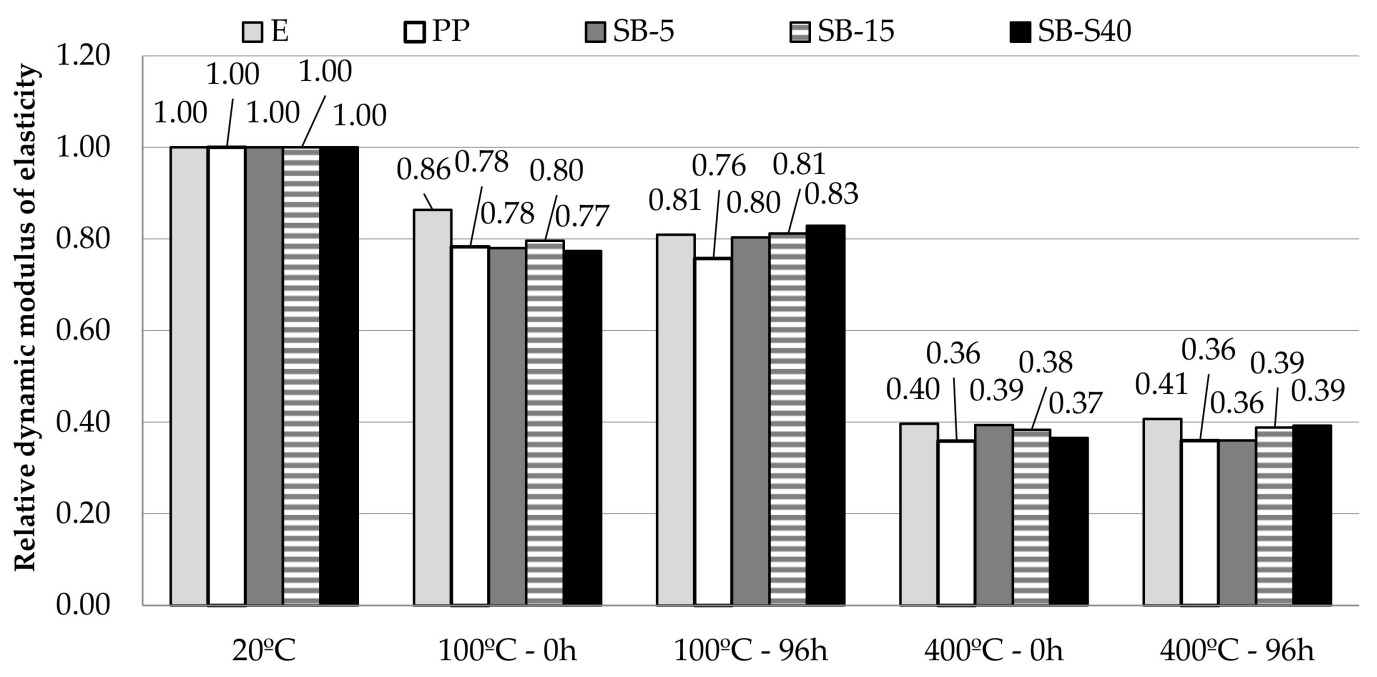

Figure 6. Residual dynamic modulus of elasticity of specimens compared with the dynamic modulus of elasticity of the same mixture at room temperature.

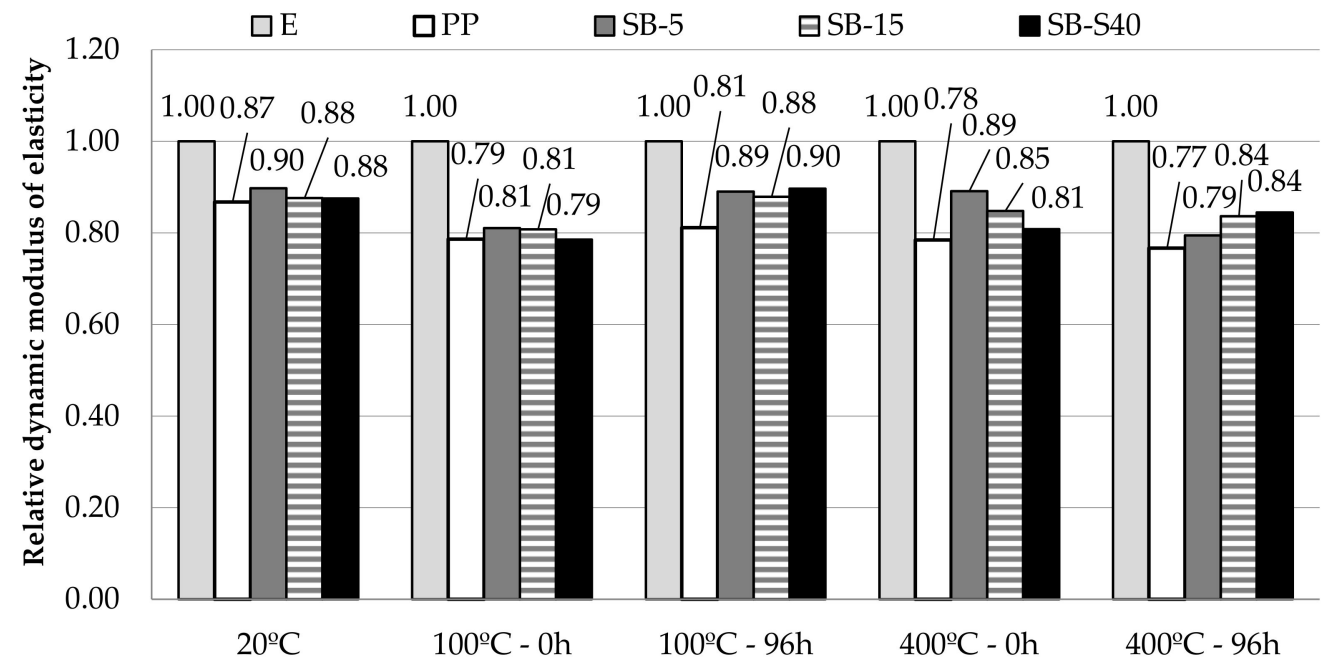

Figure 7. Residual dynamic modulus of elasticity of reinforced concretes compared with reference mixture E under the same testing conditions. 
In Table 4, the standard deviation shows that the tested samples in the series had a uniform dynamic modulus of elasticity. The largest deviation was observed in PP samples tested after drying at $100{ }^{\circ} \mathrm{C}(96 \mathrm{~h}): \pm 2.4 \mathrm{GPa}$. According to Table 4 , the ultrasonic pulse velocity (UPV) values show that some changes occurred in the concrete structure. The UPV of all mixtures at room temperature was higher than $4000 \mathrm{~m} / \mathrm{s}$, which is considered a good-quality concrete [48]. After exposing the specimens to $400{ }^{\circ} \mathrm{C}$, all mixtures had a UPV value below $3000 \mathrm{~m} / \mathrm{s}$, indicating a poor-quality concrete. The UPV values after drying in relation to the UPV at room temperature were lower by around $10 \%$, whereas after heating, the value fell by around $40 \%$ for both cooling times (Figure 8 ). We observed a negligible change in the UPV values over the $96 \mathrm{~h}$ period, which is consistent with the results for the dynamic modulus of elasticity. According to Toric et al. [41], this indicates that no structural damage occurred to the concrete specimen after cooling in the observed short time interval. The reduction in UPV was almost the same for all test mixtures at the observed temperatures and measurement time. Figure 9 shows the UPV values relative to the reference mixture. The ultrasonic pulse velocity decreased due to the addition of fibers, and the reduction for all temperatures and cooling times was 5-11\%. A decrease in UPV due to fiber addition was reported in [49], and Hedjazi and Castilo [50] considered that the reason for this finding may be the heterogeneity and development of voids in the specimens reinforced with fibers. According to Figure 3, the decomposition process of SBfibers successfully finishes at a temperature of $400{ }^{\circ} \mathrm{C}$, so a larger drop in the UPV value was expected. The reduction in the UPV value for SB concrete is not higher than for PP concrete, although the decomposition process of PP fiber is not yet finished at this temperature. Additionally, the PP fibers melted at the observed temperature of $400{ }^{\circ} \mathrm{C}$, but there was no difference in measurements at 0 and $96 \mathrm{~h}$ after cooling. UPV was measured when the specimens reached room temperature, so we assumed the PP fibers had re-solidified.

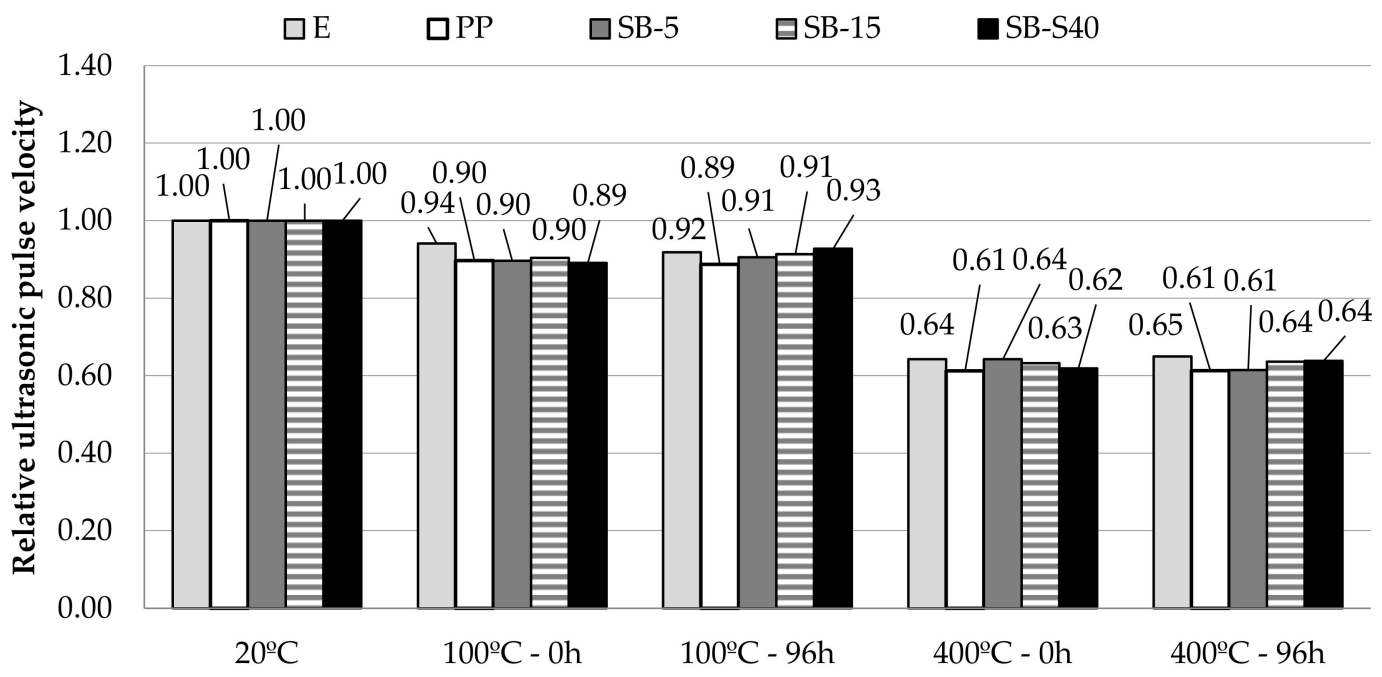

Figure 8. Residual ultrasonic pulse velocity of specimens compared with the ultrasonic pulse velocity of the same mixture at room temperature.

For a better understanding, we examined the concrete structure after exposure to an elevated temperature of $400{ }^{\circ} \mathrm{C}$ using a polarization microscope, with the results shown in Figures 10 and 11.

According to Figures 10 and 11, visible damage neither occurred in the cementaggregate contact zone nor inside the cement stone nor aggregate. Fibers can be observed in the PP and SB-S40 specimens. The fiber in SB-S40 is easier to see because of the slightly thicker greenish fibers obtained by sea maceration in which chloroplast is preserved. Figure 3 shows that at $400{ }^{\circ} \mathrm{C}$, the degradation of PP did not complete, so after cooling the specimen, the molten mass of PP fiber re-solidified; therefore, the fiber from the cement matrix was visible (Figure 10). However, Figure 3 also shows that the Spanish broom 
fiber at $400{ }^{\circ} \mathrm{C}$ should have been completely decomposed, and according to Figure 11 , it was not. The reason probably lies in the fact that the fiber behaves differently when it is directly exposed to elevated temperature and when it is surrounded and protected by a cement matrix.

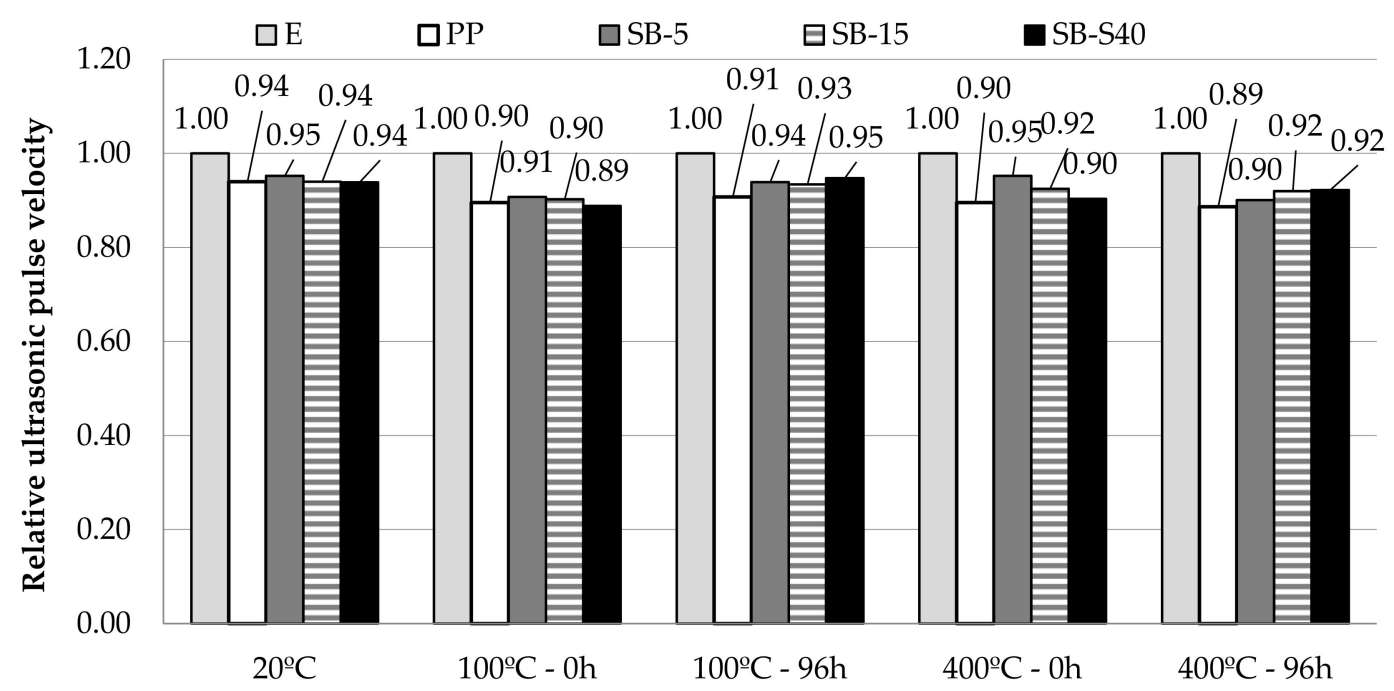

Figure 9. Residual ultrasonic pulse velocity of reinforced concretes compared with reference mixture E under the same testing conditions.

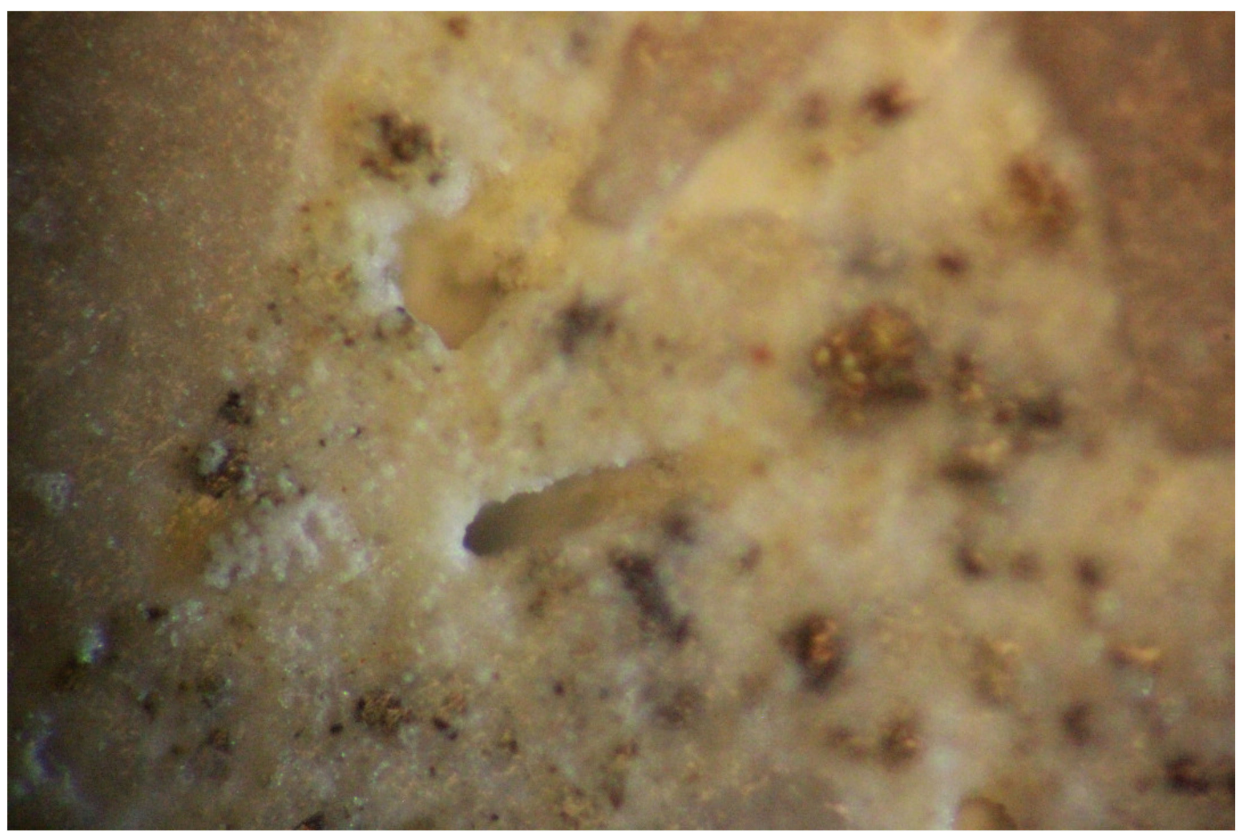

Figure 10. PP specimen after exposure to $400{ }^{\circ} \mathrm{C}$ under a polarization microscope (BK-POLR, magnification $200 \times$ ).

The compressive strength of the ordinary and reinforced concrete specimens, according to Table 4 and Figure 12, decreased after drying by about $20 \%$ and after heating by about $60 \%$, similar to the values of dynamic modulus of elasticity. According to HRN EN 1992-1-2 [51], the allowed decrease in compressive strength of ordinary concrete with limestone aggregate at $400{ }^{\circ} \mathrm{C}$ should not exceed $15 \%$ in relation to the values at room temperature $\left(20^{\circ} \mathrm{C}\right)$ and $100{ }^{\circ} \mathrm{C}$. The decrease in strength should not be caused by the chemical decomposition of hardened cement paste, because it does not occur below $400{ }^{\circ} \mathrm{C}[5,52]$. At temperatures from 100 to $400^{\circ} \mathrm{C}$, physio-chemical changes can be expected such as the 
evaporation of free water, the loss of chemically bound water, and total loss of capillary water [4]. According to [5], the pore-structure of hardened cement paste in coarsening can be regarded as the formation of equivalent cracks, which can cause the reduction in mechanical properties of concrete at $400{ }^{\circ} \mathrm{C}$. According to Figures 10 and 11, no visible damage can be observed, nor in the reference mixture in Figure 13.

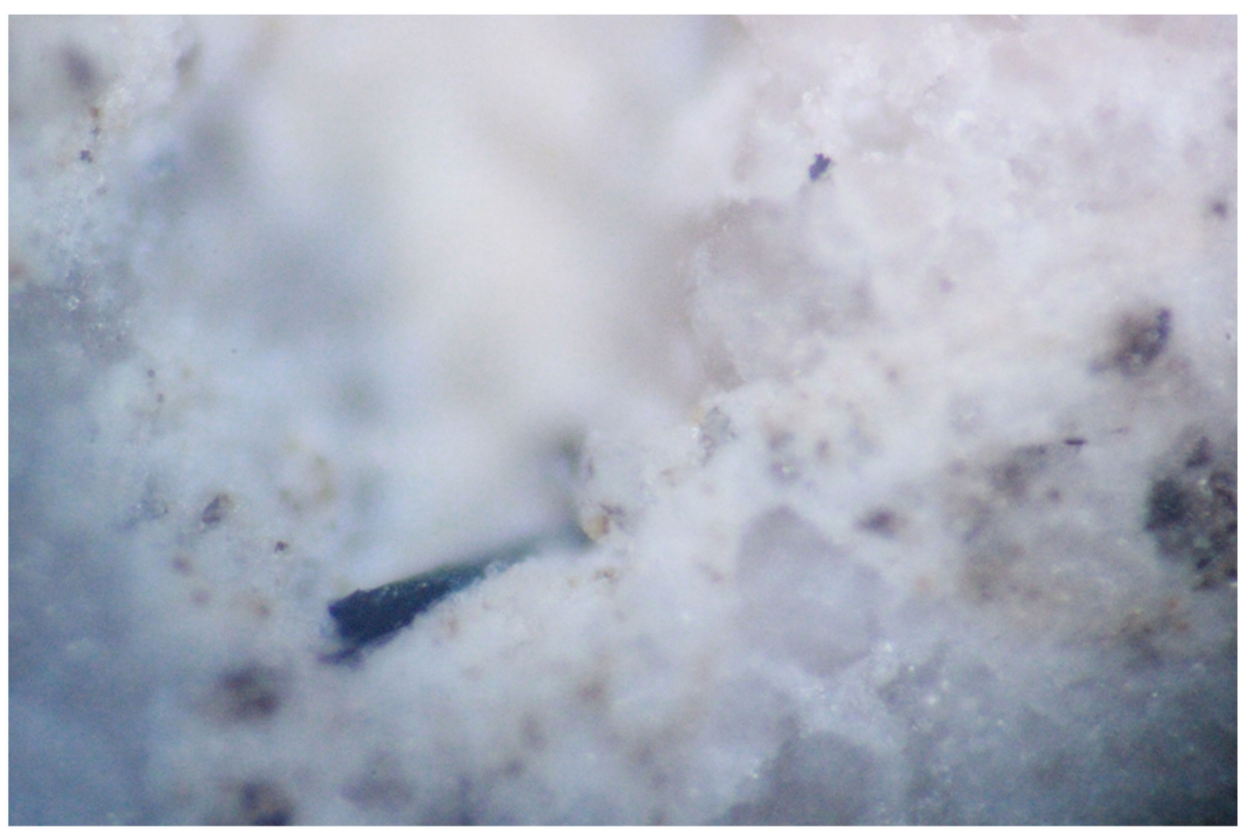

Figure 11. Specimen SB-S40 after exposure to $400^{\circ} \mathrm{C}$ under a polarization microscope (BK-POLR, magnification $100 \times$ ).

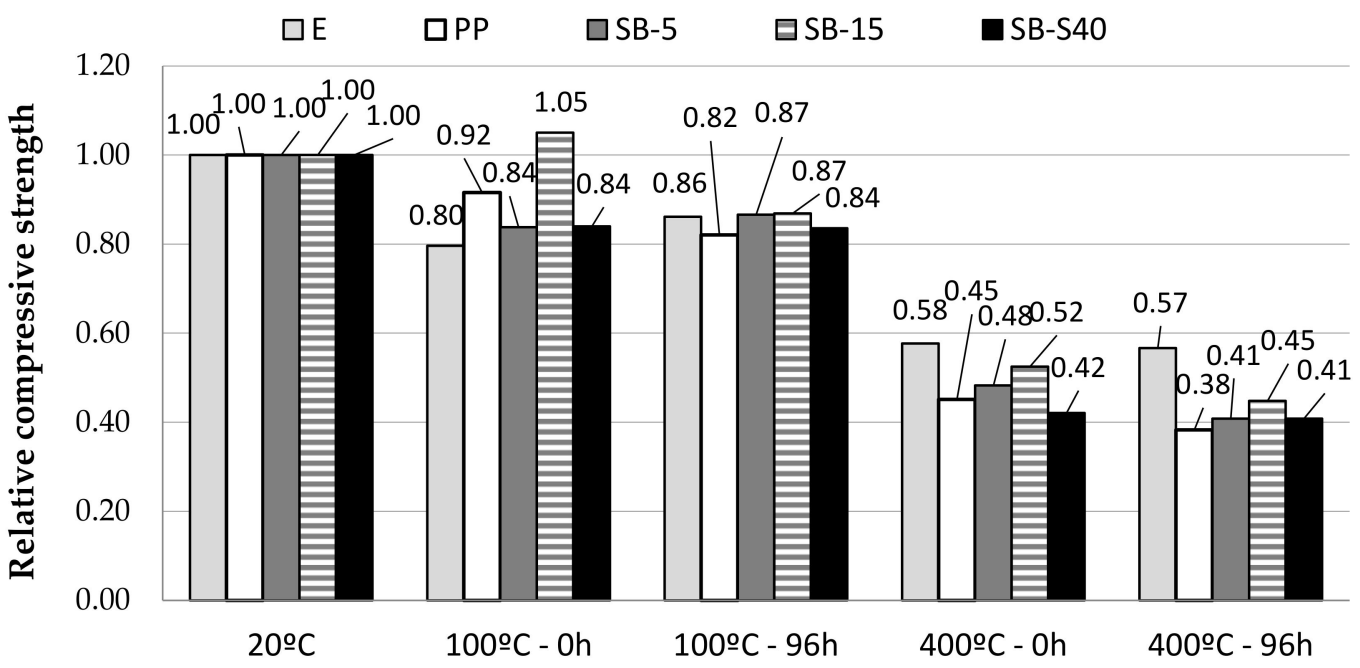

Figure 12. Residual compressive strength of specimens compared with the compressive strength of the same mixture at room temperature.

The incorporation of fibers into concrete should improve the fire resistance of concrete. According to [53-55], polypropylene (PP) fibers efficiently mitigate spalling and cracks in concrete exposed to high temperatures. The authors [56], examining the response of polypropylene fibered mortar to elevated temperature under different cooling regimes, found that the reduction in compressive strength of the mortar was significant at an elevated temperature of $400{ }^{\circ} \mathrm{C}$, and polypropylene fiber mortar behaved better than the control mortar mixture, which was not the case in our investigation, a result that may also be caused by the amount of fiber. The results after $96 \mathrm{~h}$ of cooling for PP concretes are lower 
than measured $0 \mathrm{~h}$ after cooling, although PP fibers should be completely re-solidified (Figure 12). Although the beginning of the thermal decomposition of SB fibers starts at 231 ${ }^{\circ} \mathrm{C}$ and represents a vulnerability of bio-fibers at elevated temperatures, the compressive strengths of the SB concretes were higher than that of the PP concrete.

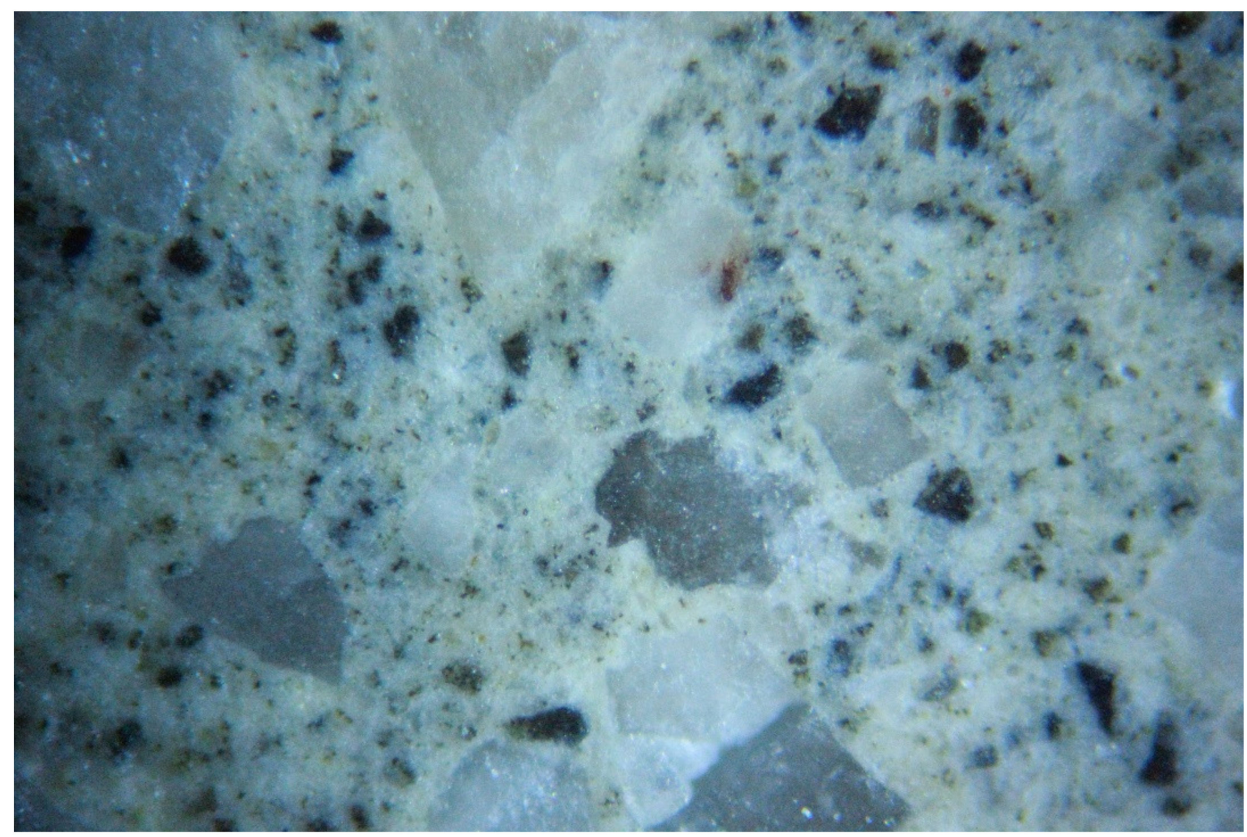

Figure 13. Specimen $\mathrm{E}$ after exposure to $400{ }^{\circ} \mathrm{C}$ under a polarization microscope (BK-POLR, magnification $100 \times)$.

Figure 14 shows the relative compressive strength ratio of the reinforced mixtures to the reference mixture. At room temperature, reinforced mixtures had higher compressive strengths than the reference mixture by $1 \%$ to $13 \%$, where the SB- 5 mixture had the highest value of $50.74 \mathrm{MPa}$. At $100{ }^{\circ} \mathrm{C}(0 \mathrm{~h})$, the increase in compressive strength of reinforced concrete was even higher and was in the range of $19 \%$ to $33 \%$. At $100{ }^{\circ} \mathrm{C}(96 \mathrm{~h})$, the PP mixture had a lower value compared to the reference mixture, and SB concretes mainly had the highest values. After heating to $400{ }^{\circ} \mathrm{C}(0 \mathrm{~h})$, reinforced mixtures had $6 \%$ to $18 \%$ lower compressive strength values compared to ordinary concrete. The compressive strengths of reinforced concretes measured after $400{ }^{\circ} \mathrm{C}(96 \mathrm{~h}$ ) were $19 \%$ to $27 \%$ lower compared to conventional concrete. At this temperature and cooling regime, SB concretes had almost the same compressive strength, which means that the maceration method did not affect the quality of the fibers at the observed temperature. The loss in compressive strength of fiber-reinforced specimens was observed over a short time interval after cooling and is not consistent with the reduction in the dynamic modulus of elasticity and UPV values. This difference in results is probably due to the determination of compressive strength being only performed once on the specimens, while the UPV and dynamic modulus of elasticity were determined on the same specimens after different test conditions (non-destructive method).

The results obtained for natural-reinforced concrete are in accordance with [4], where the authors stated that the critical temperature for natural-fiber-reinforced concrete is in the temperature range of $300-400^{\circ} \mathrm{C}$. A similar result was obtained by other authors [47] for concretes reinforced with alpha fibers. Examining the specimens after heating to $380^{\circ} \mathrm{C}$, the residual compressive strength of concrete reinforced with alpha fiber 20 and $30 \mathrm{~mm}$ in length were found to be $79 \%$ and $47 \%$, respectively, of the initial compressive strength. Ede and Aina [23] investigated the post-fire mechanical properties of 28 days old concrete reinforced with coconut husk fiber and PP fiber after heating to $400{ }^{\circ} \mathrm{C}$. They found that the degradation in the strength of concrete with coconut husk fiber was only $5.10 \%, 10.12 \%$ for PP concrete, and $15 \%$ for ordinary concrete. A significant drop in the strength of $45 \%$ 
for all concretes occurred at $600{ }^{\circ} \mathrm{C}$. Ozawa et al. [57] found that, in the temperature range of 400 to $500{ }^{\circ} \mathrm{C}$, the compressive strength of high-performance concrete with PP and jute fibers dropped sharply to $60 \%$ of the initial strength at $500{ }^{\circ} \mathrm{C}$. At $400{ }^{\circ} \mathrm{C}$, the specimens retained $80 \%$ of the initial strength.

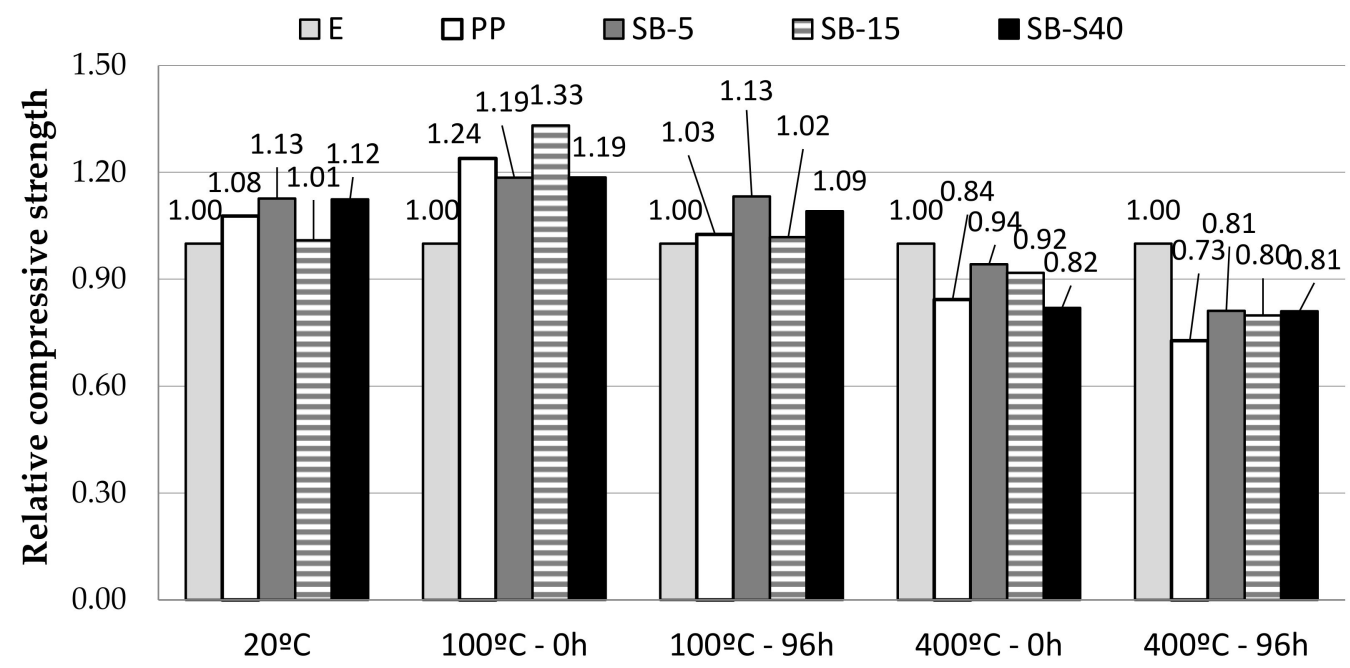

Figure 14. Residual compressive strength of reinforced concrete compared with reference mixture $\mathrm{E}$ under the same testing conditions.

An important conclusion of these authors [57] was that jute fiber could be applied for the prevention of explosive spalling, although the fiber does not improve the compressive strength of concrete. A similar conclusion can be drawn from the results in our investigation. Figure 15 shows specimens E, SB-5, SB-15, and PP on which, after exposure to $400{ }^{\circ} \mathrm{C}$, the compressive strength was tested. No test specimen underwent spalling during heating in the furnace. Spalling and explosive failure after compressive loading were visible on specimen E, whereas no such damage was visible on fiber-reinforced specimens SB-5, SB-15, and PP.

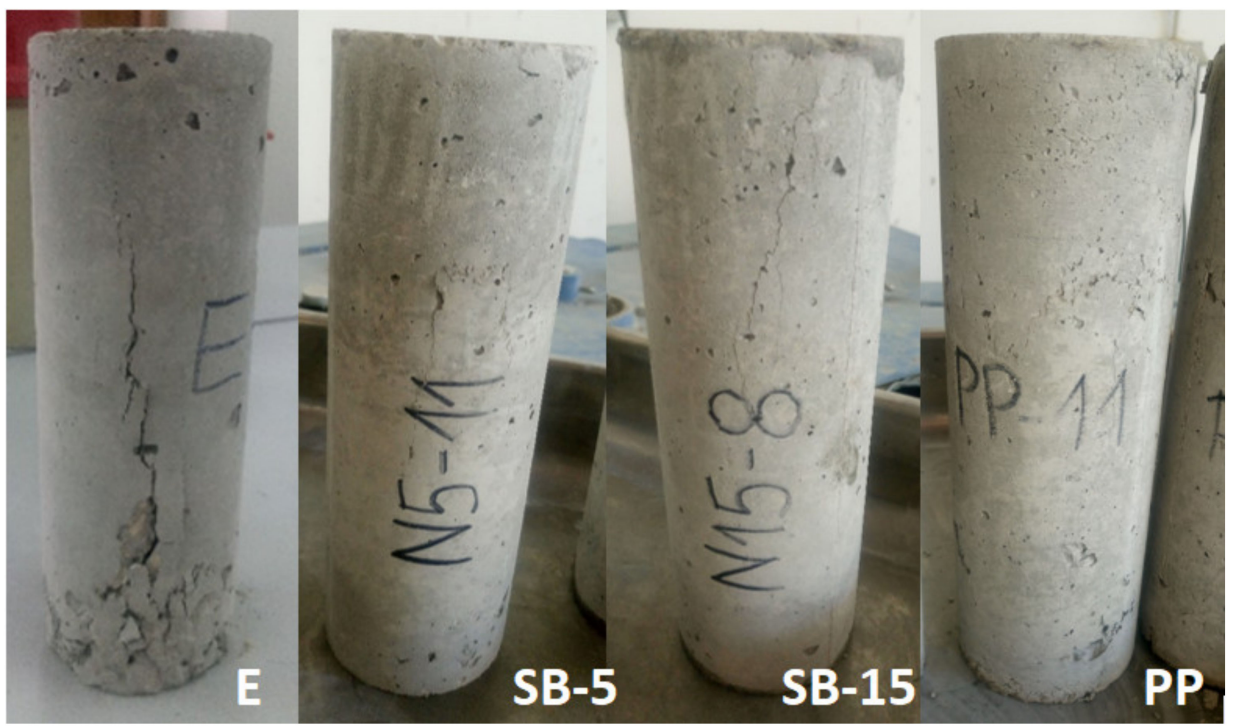

Figure 15. Specimens E, SB-5, SB-15, and PP after exposure to an elevated temperature of $400{ }^{\circ} \mathrm{C}$.

These results need further investigation to understand the behavior of concrete reinforced with Spanish broom fibers at room temperature as well as exposed to elevated temperatures, especially because these types of concrete can provide low-cost building material for residential and low-rise buildings. 


\section{Conclusions}

In this study, the mechanical and residual properties of concrete reinforced with Spanish broom and polypropylene fibers exposed to $400{ }^{\circ} \mathrm{C}$ were determined and analyzed. The specimens were tested in the fresh and hardened states. The fresh state tests showed rigid concrete consistency caused by reduced workability due to the addition of fibers to the mixture. In the hardened state, the samples were subjected to drying and heating up to $400{ }^{\circ} \mathrm{C}$. The tests in the hardened state were conducted after cooling the samples to room temperature in two stages: immediately after cooling, and $96 \mathrm{~h}$ after cooling to room temperature. Based on the tests, the following conclusions were drawn:

- The initial compressive strength at room temperature shows that the fibers improved the compressive strength of plain concrete.

- The residual values of the weight loss were almost the same in the case of the reference concrete and fiber reinforced concretes.

- All mixtures underwent almost the same reduction in ultrasonic pulse velocity at the observed temperatures. The ultrasonic pulse velocity of fiber-reinforced mixtures reduced $5-11 \%$, relative to the reference mixture at all observed temperatures and periods.

- The values of dynamic modulus of elasticity and compressive strength of the ordinary concrete and reinforced concrete specimens showed a decrease after drying of about $20 \%$ and after heating of about $60 \%$ relative to the value at room temperature. The residual compressive strength of all mixtures, even the reference concrete, decreased to lower than recommendations in HRN EN 1992-1-2.

- After drying at $100{ }^{\circ} \mathrm{C}$, the compressive strength of Spanish-broom-reinforced concrete in comparison to reference concrete was higher at 0 and $96 \mathrm{~h}$ after cooling to room temperature.

- In comparison with ordinary concrete, after heating $400{ }^{\circ} \mathrm{C}$, the residual properties of concrete reinforced with Spanish broom fibers decreased by less than those with polypropylene fibers.

- The method of maceration of Spanish broom fibers did not significantly affect the residual properties of the concrete.

- According to visual observations, Spanish broom fibers in concrete reduced the spalling and explosive failure under compressive load.

Author Contributions: Conceptualization, S.J.; methodology, S.J., I.B. and L.K.V.; validation, S.J., D.J. and I.B.; formal analysis, L.K.V.; investigation, S.J., D.J. and I.B.; resources, L.K.V., S.J. and D.J.; data curation, S.J. and D.J.; writing—original draft preparation, S.J.; writing—review and editing, D.J., I.B. and L.K.V.; visualization, S.J.; supervision, S.J., D.J. and I.B.; project administration, L.K.V.; funding acquisition, I.B. and S.J. All authors have read and agreed to the published version of the manuscript.

Funding: This research received no external funding.

Institutional Review Board Statement: Not applicable; this study did not involve humans or animals.

Informed Consent Statement: Not applicable; this study did not involve humans.

Data Availability Statement: The data presented in this study are available from the corresponding author upon request.

Acknowledgments: This research was partially supported through project KK.01.1.1.02.0027, a project co-financed by the Croatian Government and the European Union through the European Regional Development Fund-the Competitiveness and Cohesion Operational Programme and Functional integration of the University of Split, PMF-ST, PF-ST and KTF-ST through the development of scientific research infrastructure in the building of three faculties (KK.01.1.1.02.0018); the project was co-financed by the European Union from the European Regional Development Fund.

Conflicts of Interest: The authors declare no conflict of interest. 


\section{References}

1. Kim, S.; Oli, T.; Park, C. Effect of Exposure to High Temperature on the Mechanical Properties of SIFRCCs. Appl. Sci. 2020, 10, 2142. [CrossRef]

2. ACI Committee 554. Report on Fiber Reinforced Concrete, 544.1R-96, Reapproved 2002; pp. 1-66. Available online: http: / /indiafiber.com/Files/ACI\%20report.pdf (accessed on 2 August 2021).

3. Löfgren, I. Fibre-Reinforced Concrete for Industrial Construction-A Fracture Mechanics Approach to Material Testing and Structural Analysis; Department of Civil and Environmental Engineering-Structural Engineering, Chalmers University of Technology: Göteborg, Sweden, 2005.

4. Aluko, O.G.; Yatim, J.M.; Kadir, M.A.A.; Yahya, K. A review of properties of bio-fibrous concrete exposed to elevated temperatures. Constr. Build. Mater. 2020, 260, 119671. [CrossRef]

5. Peng, G.-F.; Huang, Z.-S. Change in microstructure of hardened cement paste subjected to elevated temperatures. Constr. Build. Mater. 2008, 22, 593-599. [CrossRef]

6. Khoury, G.A. Effect of fire on concrete and concrete structures. Prog. Struct. Eng. Mater. 2000, 2, 429-447. [CrossRef]

7. Nurchasanah, Y.; Alfitouri, M.; Solikin, M. Steel Fiber Reinforced Concrete to Improve the Characteristics of Fire-Resistant Concrete. Appl. Mech. Mater. 2016, 845, 220-225. [CrossRef]

8. Lau, A.; Anson, M. Effect of high temperatures on high performance steel fibre reinforced concrete. Cem. Concr. Res. 2006, 36, 1698-1707. [CrossRef]

9. Xiao, J.; Falkner, H. On residual strength of high-performance concrete with and without polypropylene fibres at elevated temperatures. Fire Saf. J. 2006, 41, 115-121. [CrossRef]

10. Sideris, K.K.; Manita, P.; Chaniotakis, E. Performance of thermally damaged fibre reinforced concretes. Constr. Build. Mater. 2009, 23, 1232-1239. [CrossRef]

11. Amancio, F.A.; De Carvalho Rafael, M.F.; De Oliveira Dias, A.R.; Bezerra Cabral, A.E. Behavior of concrete reinforced with polypropylene fiber exposed to high temperatures. Procedia Struct. Integr. 2018, 11, 91-98. [CrossRef]

12. Kalifa, P.; Chéné, G.; Gallé, C. High-temperature behaviour of HPC with polypropylene fibres-From spalling to microstructure. Cem. Concr. Res. 2001, 31, 1487-1499. [CrossRef]

13. Peças, P.; Carvalho, H.; Salman, H.; Leite, M. Natural Fibre Composites and Their Applications: A Review. J. Compos. Sci. 2018, 2, 66. [CrossRef]

14. Aziz, M.A.; Paramasivam, P.; Lee, S.L. Prospects of Natural Fiber Reinforced Concretes in Construction. Int. J. Cem. Compos. Lightweight Concr. 1981, 3, 123-132. [CrossRef]

15. Ratna Prasad, A.V.; MohanaRao, K. Mechanical properties of natural fibre reinforced polyester composites: Jowar, sisal and bamboo. Mater. Des. 2011, 32, 4658-4663. [CrossRef]

16. Azwa, Z.N.; Yousif, B.F.; Manalo, A.C.; Karunasena, W. A review on the degradability of polymeric composites based on natural fibres. Mater. Des. 2013, 47, 424-442. [CrossRef]

17. Ogunbode, E.B.; Egba, E.I.; Olaiju, O.A.; Elnafaty, A.S.; Kawuwa, S.A. Microstructure and mechanical properties of Green concrete composites containing coir fibre. Chem. Eng. Trans. 2017, 61, 1879-1884.

18. Ralegaonkar, R.; Gavali, H.; Aswath, P.; Abolmaali, S. Application of chopped basalt fibers in reinforced mortar: A review. Constr. Build. Mater. 2018, 164, 589-602. [CrossRef]

19. Booya, E.; Gorospe, K.; Ghaednia, H.; Das, S. Durability properties of engineered pulp fibre reinforced concretes made with and without supplementary cementitious materials. Compos. Part B Eng. 2019, 172, 376-386. [CrossRef]

20. Onuaguluchi, O.; Banthia, N. Plant-based natural fibre reinforced cement composites: A review. Cem. Concr. Compos. 2016, 68, 96-108. [CrossRef]

21. Jami, T.; Karade, S.R.; Singh, L.P. A review of the properties of hemp concrete for green building applications. J. Clean. Prod. 2019, 239, 117852. [CrossRef]

22. Sen, T.; Reddy, H.N.J. Various Industrial Applications of Hemp, Kinaf, Flax and Ramie Natural Fibres. Int. J. Innov. Manag. Technol. 2011, 2, 192-198.

23. Ede, A.N.; Aina, A.O. Effects of Coconut Husk and Propylene Fiber on the Fire Resistance of Concrete. Int. J. Eng. Sci. Manag. 2015, 5, 171-179.

24. Anowai, S.I.; Job, O.F. Durability properties of banana fibre reinforced fly ash concrete. Int. Res. J. Eng. Technol. 2017, 4, 1168-1174.

25. Nwankwo, P.O.; Achuenu, E. Compressive Behaviour of Sisal Fibre Reinfoced Ternary Concrete at Elevated Temperatures. Int. J. Adv. Res. Technol. 2014, 3, 123-131.

26. Netinger Grubeša, I.; Marković, B.; Gojević, A.; Brdarić, J. Effect of hemp fibers on fire resistance of concrete. Constr. Build. Mater. 2018, 184, 473-484. [CrossRef]

27. Juradin, S.; Boko, I. Possibility of cement composite reinforcement by Spanish broom fibres. Gradevinar 2018, 70, 487-495.

28. Juradin, S.; Boko, I.; Netinger Grubeša, I.; Jozić, D.; Mrakovčić, S. Influence of different treatment and amount of Spanish broom and hemp fibres on the mechanical properties of reinforced cement mortars. Constr. Build. Mater. 2021, 273, 121702. [CrossRef]

29. Juradin, S.; Boko, I.; Netinger Grubeša, I.; Jozić, D.; Mrakovčić, S. Influence of harvesting time and maceration method of Spanish Broom (Spartium junceum L.) fibers on mechanical properties of reinforced cement mortar. Constr. Build. Mater. 2019, 225, $243-255$. [CrossRef] 
30. Juradin, S.; Boko, I.; Netinger Grubeša, I.; Jozić, D.; Mrakovčić, S. Effects of different chemical pretreatments of natural fibers on the mechanical properties of cement mortar. In Proceedings of the International Conference on Sustainable Materials, Systems and Structures, Rovinj, Croatia, 20-22 March 2019; Ivanković, A.M., Marić, M.K., Staruss, A., Kišiček, T., Eds.; RILEM Publications S.A.R.L., Curran Associates, Inc.: West Chester, OH, USA, 2019; pp. 195-201.

31. Juradin, S.; Boko, I.; Netinger Grubeša, I.; Jozić, D.; Mrakovčić, S.; Vukojević, I. Properties of Spanish Broom Fiber Reinforced Concrete. Solid State Phenom. 2021, 322, 72-77. [CrossRef]

32. Katović, D.; Katović, A.; Krnčević, M. Spanish Broom (Spartium junceum L.)—History and Perspective. J. Nat. Fibers. 2011, 8, 81-98. [CrossRef]

33. Verma, D.; Goh, K.L. Effect of Mercerization/Alkali Surface Treatment of Natural Fibres and Their Utilization in Polymer Composites: Mechanical and Morphological Studies. J. Compos. Sci. 2021, 5, 175. [CrossRef]

34. HRN EN 197-1:2012 Cement-Part 1: Composition, Specifications and Conformity Criteria for Common Cements (EN 197-1:2011). Available online: https:/ / repozitorij.hzn.hr/norm/HRN+EN+197-1\%3A2012 (accessed on 2 August 2021).

35. Toraya, H. Direct derivation (DD) of weight fractions of individual crystalline phases from observed intensities and chemical composition data: Incorporation of the DD method into the whole-powder-pattern fitting procedure. J. Appl. Cryst. 2018, 51, 446-455. [CrossRef]

36. HRN EN 12350-6:2019 Testing Fresh Concrete-Part 6: Density (EN 12350-6:2019). Available online: https://repozitorij.hzn.hr/ norm/HRN+EN+12350-6\%3A2019 (accessed on 2 August 2021).

37. HRN EN 12350-7:2019 Testing Fresh Concrete-Part 7: Air Content—Pressure Methods (EN 12350-7:2019). Available online: https:/ / repozitorij.hzn.hr/norm/HRN+EN+12350-7\%3A2019 (accessed on 2 August 2021).

38. HRN EN 12350-2:2019 Testing Fresh Concrete-Part 2: Slump Test (EN 12350-2:2019). Available online: https:/ / repozitorij.hzn. $\mathrm{hr} /$ norm/HRN+EN+12350-2\%3A2019 (accessed on 2 August 2021).

39. HRN U.M1.032:1981 Temperature Measuring of Fresh Concrete; Library of the Faculty of Civil Engineering, Architecture and Geodesy, University of Split: Split, Croatia, 1981.

40. Bamigboye, G.; Ngene, B.; Aladesuru, O.; Mark, O.; Adegoke, D.; Jolayemi, K. Compressive Behaviour of Coconut Fibre (Cocos nucifera) Reinforced Concrete at Elevated Temperatures. Fibers 2020, 8, 5. [CrossRef]

41. Torić, N.; Boko, I.; Juradin, S.; Baloević, G. Mechanical properties of lightweight concrete after fire exposure. Struct. Concr. 2016, 17, 1071-1081. [CrossRef]

42. RILEM TC 129 MHT. Test methods for mechanical propertiesof concrete at high temperatures-Part 3: Compressive strength for service and accident conditions. Mater. Struct. 1995, 28, 410-414. [CrossRef]

43. RILEM TC 200 HTC. Mechanical concrete properties at high temperatures-Modelling and applications-Part 1: Introduction, General presentation. Mater. Struct. 2007, 40, 841-853. [CrossRef]

44. HRN EN 12504-4:2021 Testing Concrete-Part 4: Determination of Ultrasonic Pulse Velocity. Available online: https:/ / repozitorij. hzn.hr/norm/HRN+EN+12504-4\%3A2021 (accessed on 2 August 2021).

45. HRN EN 12390-3:2019 Testing Hardened Concrete-Part 3: Compressive Strength of Test Specimen. Available online: https: / / repozitorij.hzn.hr/norm/HRN+EN+12390-3\%3A2019 (accessed on 2 August 2021).

46. Naus, D.J. The Effect of Elevated Temperature on Concrete Materials and Structures-A Literature Review; Oak Ridge National Laboratory: Oak Ridge, TN, USA, 2006; p. 204.

47. Mihoub, I.; Khelifa, M.R.; Mezhoud, S. Impact of elevated temparture on the properties of concrete reinforced with alfa fiber. Civ. Environ. Eng. Rep. 2020, 30, 161-185. [CrossRef]

48. Ultrasonic Pulse Velocity Meter. Available online: https://www.iricen.gov.in/LAB/res/pdf/test-32.pdf (accessed on 9 August 2021).

49. Al Rawi, K.H.; Al Khafagy, M.A.S. Effect of adding sisal fiber and Iraqi bauxite on some properties of concrete. J. Tech. 2011, 24, 58-73.

50. Hedjazi, S.; Castillo, D. Relationships among compressive strength and UPV of concrete reinforced with different types of fibers. Heliyon 2020, 6, e03646. [CrossRef] [PubMed]

51. HRN EN 1992-1-2:2013/ A1:2019, Eurocode 2: Design of Concrete Structures-Part 1-2: General Rules-Structural Fire Design (EN 1992-1-2:2004/A1:2019)). Available online: https://repozitorij.hzn.hr/norm/HRN+EN+1992-1-2\%3A2013\%2FA1\%3A2019 (accessed on 2 August 2021).

52. Ibrahim, R.K.; Hamid, R.; Taha, M.R. Fire resistance of high-volume fly ash mortars with nanosilica addition. Constr. Build. Mater. 2012, 36, 779-786. [CrossRef]

53. Sideris, K.K.; Manita, P. Residual mechanical characteristics and spalling resistance of fiber reinforced self-compacting concretes exposed to elevated temperatures. Constr. Build. Mater. 2013, 41, 296-302. [CrossRef]

54. Sanchayan, S.; Foster, S.J. High temperature behaviour of hybrid steel-PVA fibre reinforced reactive powder concrete. Mater. Struct. Constr. 2016, 49, 769-782. [CrossRef]

55. Bangi, M.R.; Horiguchi, T. Effect of fibre type and geometry on maximum pore pressures in fibre-reinforced high strength concrete at elevated temperatures. Cem. Concr. Res. 2012, 42, 459-466. [CrossRef]

56. Karahan, O.; Durak, U.; İlkentapar, S.; Atabey, I.I.; Atiş, C.D. Resistance of polypropylene fibered mortar to elevated temperature under different cooling regimes. J. Construct. 2019, 18, 386-397. [CrossRef]

57. Ozawa, M.; Sato, R.; Yoon, M.-H.; Rokugo, K.; Kim, G.-Y.; Choe, G.-C. Thermal properties of jute fiber concrete at high temperature. J. Struct. Fire Eng. 2017, 7, 182-192. [CrossRef] 